\title{
SOME PSYCHOLOGICAL AND SOCIAL CHARACTERISTICS OF PATIENTS HOSPITALIZED FOR RHEUMATOID ARTHRITIS, HYPERTENSION, AND DUODENAL ULCER
}

\author{
Sidney Cobb, M.D.*, Stanislay V. Kasl, Ph.D. $\dagger$, Edith Chen, M.A. $\ddagger$ and Roger \\ ChristenfelD, M.A. $\S$
}

Institute for Social Research, The University of Michigan, Ann Arbor, Michigan

(Received 6 December 1964)

THE PURPOSE of this report is to compare men hospitalized for rheumatoid arthritis, hypertension, or duodenal ulcer with patients from the surgical wards and with brothers and/or brothers-in-law of all of the above four groups. The comparisons are made with respect to the subjects' interview reports of their: (1) achievement, selfesteem, and desire for change; (2) perception of parents; (3) past and present happiness and the frequency of life crises; (4) certain discrepancies in the perceptions of the subjects and their respective brothers or brothers-in-law; and (5) aggressive and impulsive behavior. The initial impetus to this exploratory study was a set of preliminary hypotheses concerning the differences to be found between patients with rheumatoid arthritis and all of the other groups of patients and controls. However, since the pattern of results is too complex to be adequately represented in the form of a series of such simple comparisons, the findings are presented by taking one variable at a time and noting the differences among all of the groups of patients and controls. In the discussion section, the results are reviewed by disease and by patients $v s$. controls.

\section{METHODS}

The data were collected from male patients in a Veterans Administration Hospital and from their brothers and brothers-in-law by two non-medical interviewers using a formal interview schedule. Patients were accepted for the study on the basis of the A.R.A. criteria for definite rheumatoid arthritis [1] or satisfactory clinical criteria for essential hypertension or duodenal ulcer. The original case selections were made by an internist of the hospital staff and the case records were reviewed by the senior author after the patient had been discharged. Persons having more than one of the three psychosomatic diseases were excluded. The hospital control cases came from the surgical service with the following diagnoses: hemorrhoids and related rectal disease 14 , osteomyelitis 8 , miscellaneous orthopedic conditions 9 , hernia 2 , varicose veins 1 .

*Program Director, Survey Research Center, University of Michigan. Formerly Associate Professor of Epidemiology, University of Pittsburgh.

tStudy Director, Research Center for Group Dynamics, University of Michigan.

¥Formerly Research Associate in Epidemiology, University of Pittsburgh.

\$Formerly Assistant Study Director, Research Center for Group Dynamics, University of Michigan. 
Table 1. Mean age of PATIENTS AND their controls

\begin{tabular}{lcccccr}
\hline \multirow{2}{*}{ Disease classification } & \multicolumn{2}{c}{ Patients } & & \multicolumn{2}{c}{ Brothers and brothers-in-law } \\
\cline { 2 - 3 } \cline { 6 - 7 } & No. of cases & Mean age & & No. of cases & Mean age \\
\hline Rheumatoid arthritis & 25 & 48.0 & & 21 & 48.1 \\
Hypertension & 14 & 53.6 & & 8 & 48.4 \\
Duodenal ulcer & 36 & 40.9 & & 30 & 42.3 \\
Surgical patients & 34 & 42.1 & & 30 & 42.2 \\
Total & 109 & 44.5 & & 89 & 44.2 \\
\hline
\end{tabular}

In trying to secure the non-hospitalized controls, it proved impossible in some instances to interview the brother or the brother-in-law, so that, as can be seen in Table 1, there are not quite as many individuals from the community as from the hospital. After the study was underway, it was suggested that some questions on happiness and related affcets should be included. The result, of coursc, is that the number of cases available for analysis is smaller for these variables.

\section{RES U L T S}

The demographic variables will be examined first in order to determine how the four groups of patients compare with each other, and with their controls, the brothers and brothers-in-law. Table 1 presents the mean ages of the subjects as of the time of the study. It may be seen that the attempt to balance the brothers and brothers-in-law with the patients with regard to age was reasonably successful. The age differences across the patient groups are significant and reflect the age distribution of these several disease categories. We have been on the alert for age effects in our data but have found that our social and psychological variables are not age-related. No corrections for age have therefore been applied.

The data presentation which follows will differ from the format of Table 1 in several respects: (1) The number of cases in each patient group will fluctuate somewhat, depending on missing information on a particular variable. (2) The several groups of brothers and brothers-in-law will be collapsed into a single control group, which will then be contrasted with the four groups of patients. This control group includes some additional 28 cascs, controls for patients with doubtful diagnoses where the patients themselves are omitted. (3) This collapsing of the several control groups is justified on the grounds that no significant differences among them were found for any of the variables under study.

Table 2 lists the demographic and background variables on which we did not find significant differences, either between the several patient groups or between the patients and their controls. It may be seen that, except with regard to age, we are dealing with comparable groups of subjects. The major characteristics, describing the total subject population, are summarized in this table.

It is worth noting that differences on the last variable in Table 2, subject's occupation, reached borderline significance $\left(\chi^{2}=8.9,4\right.$ d.f., $\left.P=0.07\right)$ which is entirely accounted for by the fact that all of the rheumatoid arthritis patients have manual occupations, as compared with 75 per cent of the controls and 79 per cent of the other patients. While it is inappropriate to select out for comment one extreme group when 
TABle 2. DEmographic and background characteristics of PATIENTS AND their CONTROLS (For these variables there were no significant differences between groups)

1. Father's occupation: $95 \%$ in manual work.

2. Father's education: a mean of 6.7 years of schooling.

3. Mother's education: a mean of 7.4 years of schooling.

4. Number of siblings: a mean of 4.9 siblings.

5. Father's church attendance: $67 \%$ attend church 'frequently'.

6. Mother's church attendance: $79 \%$ attended church 'frequently'.

7. Father's general health (subject's report): 'good' in $84 \%$ of cases.

8. Mother's general health (subject's report): 'good' in $85 \%$ of cases.

9. Subject's religion : $53 \%$ Protestants, $40 \%$ Catholics, $2 \%$ Jews.

10. Number of children : a mean of 2.3 children.

11. Subject's church attendance : $39 \%$ attend 'frequently'.

12. Subject's occupation: $79 \%$ in manual work.

the overall test of significance does not warrant the rejection of the null hypothesis, the result is nevertheless consistent with other studies showing a mild negative association between occupational status and rheumatoid arthritis [2,3]. Moreover, it can be supported by additional evidence. It we eliminate from study the 5 per cent of subjects' fathers who have white-collar jobs, then we hold father's occupation constant and we can look at the occupational mobility of the subjects: 22 per cent of the controls move up to white collar jobs as compared with none for the arthritis patients $(P<0.01$ for the difference in the two percentages). The other three patient groups are like the controls.

Table 3 presents data on educational attainment which closely parallel the occupational findings. The arthritis patients again stand out as a group with minimal upward mobility inasmuch as their attained level of education exceeds their parents' level much less than the other patients' and the controls'.

The above findings on occupational and educational attainment and mobility are nicely supplemented by our findings on two psychological variables: desire for

TABLE 3. RELATIONSHTP OF EDUCATIONAL ATTAINMENT TO DISEASE CLASSIFICATION

\begin{tabular}{|c|c|c|c|c|c|c|}
\hline \multirow{2}{*}{$\begin{array}{c}\text { Disease } \\
\text { classification }\end{array}$} & \multirow{2}{*}{$\begin{array}{c}\text { Mean } \\
\text { number of } \\
\text { years of } \\
\text { subject's } \\
\text { education }\end{array}$} & \multirow{2}{*}{$\begin{array}{l}\text { No. of } \\
\text { cases }\end{array}$} & \multicolumn{4}{|c|}{$\begin{array}{c}\text { Mean number of years of subject's education } \\
\text { beyond level attained by }\end{array}$} \\
\hline & & & $\begin{array}{l}\text { Subject's } \\
\text { father }\end{array}$ & $\begin{array}{l}\text { No. of } \\
\text { cases }\end{array}$ & $\begin{array}{l}\text { Subject's } \\
\text { mother }\end{array}$ & $\begin{array}{l}\text { No. of } \\
\text { cases }\end{array}$ \\
\hline Rheumatoid arthritis & 9.0 & 25 & 1.0 & 11 & 0.5 & 15 \\
\hline Hypertension & 8.5 & 14 & 3.4 & 8 & 3.1 & 9 \\
\hline Ulcer & 9.7 & 36 & 6.0 & 19 & 3.5 & 20 \\
\hline Surgical patients & 9.7 & 34 & 3.6 & 17 & 3.0 & 17 \\
\hline Controls & 10.4 & 116 & 4.7 & 71 & 3.9 & 73 \\
\hline Analysis of variance & \multicolumn{2}{|c|}{$\begin{aligned} F & =2.59 \\
\text { d.f. } & =4: 220 \\
P & <0.05\end{aligned}$} & \multicolumn{2}{|c|}{$\begin{array}{c}F=3.64 \\
\text { d.f. }=4: \quad 121 \\
P<0.01\end{array}$} & \multicolumn{2}{|c|}{$\begin{array}{c}F=2.52 \\
\text { d.f. }=4: 129 \\
P<0.05\end{array}$} \\
\hline
\end{tabular}


changes in self, and self-esteem. The measure of the former variable is made up of the answers to the following question:

Indicate whether you would like to change any of the following things about yourself: (1) habits; (2) abilities; (3) family relationships; (4) social relationships; (5) other (specify).

Table 4 presents the differences among groups in this variable, which has been dichotomized approximately at the median. It is readily seen that arthritis patients, showing lowest actual mobility, are most unwilling to see changes in themselves. The ulcer patients, on the other hand, exceed their parents' level of education most and also show a high willingness to change themselves.

Table 4. Relationship of DESIRE For chanoes in Self to disease Classification (Percentage of cases)

\begin{tabular}{lcccccc}
\hline & $\begin{array}{c}\text { Rheumatoid } \\
\text { arthritis }\end{array}$ & $\begin{array}{c}\text { Hyper- } \\
\text { tension }\end{array}$ & Ulcer & $\begin{array}{c}\text { Surgical } \\
\text { patients }\end{array}$ & Controls & Total \\
\hline Wants to change self & 4 & 29 & 44 & 35 & 30 & 30 \\
Unwilling to change self & 96 & 71 & 56 & 65 & 70 & 70 \\
\hline Total number & 25 & 14 & 36 & 34 & 116 & 225 \\
\hline & $x^{2}=12.0$ & d.f. $=4$ & & $P<0.025$ & &
\end{tabular}

It is worth noting the overall relationship between educational attainment and desire for change in self: subjects wanting to change exceed their fathers' education by 5.5 years of schooling, whereas subjects not wanting to change exceed it only by 3.7 years $(t=2.61$, d.f. $=123, P<0.005)$. The corresponding numbers for years exceeding mothers' education are 3.8 and 3.0 years; the difference is in the same direction but is not significant $(t=1.16$, d.f. $=131, P=0.12)$. Moreover, subjects wanting to change tend to come from families where the mother's education exceeds the father's, whereas subjects unwilling to change have parents whose years of education are about the same $(t=2.16$, d.f. $=114, P<0.02)$. The meaning of the association between educationa! mobility and desire for change is a bit ambiguous. It is likely, however, that the index of desire for change reflects a fairly stable personality characteristic which might have been once partly instrumental in higher educational achievement among our subjects. It is aiso possible that high educational achievement leads to greater appreciation of ones deficiencies and hence a greater desire for change. On the whole we favor the former explanation but must admit that the latter may contribute as well. This lack of desire for change among rheumatoids has been noted before [4].

The measure of self-esteem consists of three items:

1. If you had a son, would you like him to be similar to you?

2. How would you rate your performance on a job?

3. When you have a real difficulty in doing a job, what do you usually do?

The answers which indicate high self-evaluation or self-esteem are: would like his son to be similar to him, rates his performance highly and works harder on his own in order to overcome the difficulty on a job. Our previous work [5] suggests, both on 
theoretical and empirical grounds, that self-esteem and occupational status will be positively correlated. In the present study, using a somewhat different measure of selfesteem, we find that indeed, white collar workers have higher self-esteem than manual workers $(t=2.90$, d.f. $=220, P<0.005)$. This same difference can be expressed as a biserial correlation of 0.27 . Table 5 presents the relationship of self-esteem to our disease categories. All the patient groups appear to have a somewhat lower selfesteem than their brothers and brothers-in-law. An additional interesting point comes to light when we look at the correlation between self-esteem and desire for change: among the 116 controls, low self-evaluation is accompanied by high desire for change $(r=-0.27, P<0.005$ ), whereas among the 109 patients from among the several disease categories, the direction of the relationship is reversed $(r=0.13$, n.s.). The difference between the correlations is highly significant $(P<0.005)$.

TABLE 5. RELATIONSHIP OF SELF-ESTEEM TO DISEASE CLASSIFICATION

(Percentage of cases)

\begin{tabular}{lcccccc}
\hline & $\begin{array}{c}\text { Rheumatoid } \\
\text { arthritis }\end{array}$ & $\begin{array}{l}\text { Hyper- } \\
\text { tension }\end{array}$ & Ulcer & $\begin{array}{l}\text { Surgical } \\
\text { patients }\end{array}$ & Controls & Total \\
\hline Low self-esteem & 56 & 64 & 47 & 56 & 32 & 43 \\
High self-esteem & 44 & 36 & 53 & 44 & 68 & 57 \\
\hline Total number & 25 & 14 & 36 & 34 & 117 & 226 \\
\hline & $x^{2}=12.2$ & d.f. $=4$ & & $P<0.025$ & &
\end{tabular}

Let us now turn to a number of psychological variables, all dealing with the subjects perceptions of their parents and of their childhood. The first scale is made up from the following five items, describing the behavior of the father and the mother, as recalled by the subject:

1. When you were a child, how often did you feel that your (father/mother) paid attention to you?

2. How often did your (father/mother) show strong affection toward their children?

3. How would you rate (his/her) discipline in terms of consistency?

4. As a child, how often did you feel that your (father/mother) punished you when you didn't deserve it?

5. How often was your (father/mother) mean to you when you were a child?

On this scale the perceptions of father and mother correlate 0.82 , suggesting that the subjects' perceptions of paternal and maternal affection-attention are not differentiated very much. In a past study. [6], these items mildly differentiated a group of female patients with rheumatoid arthritis from their controls. In the present study of male patients in several diagnostic categories, no significant differences were found.

Let us next turn our attention to a scale which attempts to assess the relative influence of masculine and feminine figures in the subject's youth. It consists of the following four items:

1. Who was the principal disciplinarian in your family?

2. Whom did you admire the most in your family when you were growing up?

3. Who had the most influence on you while you were growing up?

4. Up to the time you were sixteen, to whom did you feel most attached in your family? 
From Table 6 it is apparent that rheumatoid arthritis and ulcer patients report more frequently, and surgical patients less frequently, a feminine figure (primarily the mother) as being the most influential in their childhood. We do not know, to be sure, to what extent this measure reflects the actual situation in the subjects' homes during their childhood rather than some later distortion of memory. However, it is possible for us to argue that this measure is more than an autistic distortion of memory, for the correlation of the scores on this measure for the 46 available pairs of siblings, each patient and his brother independently describing his parents' behavior, is $0.54(P<0.001)$. This is an impressive enough correlation, considering that the estimated odd-even, split-half reliability of this very short scale is only 0.60 .

TABLE 6. AsSOcIATION OF THE NATURE OF RECALIED PARENT-CHILD RELATIONSHIP WTTH DISEASE CLASSIFICATION

(Percentage of cases)

\begin{tabular}{|c|c|c|c|c|c|c|}
\hline & $\begin{array}{l}\text { Rheumatoid } \\
\text { arthritis }\end{array}$ & $\begin{array}{l}\text { Hyper- } \\
\text { tension }\end{array}$ & Ulcer & $\begin{array}{l}\text { Surgical } \\
\text { patients }\end{array}$ & Controls & Total \\
\hline Feminine figure dominant & 80 & 57 & 64 & 29 & 52 & 54 \\
\hline Masculine figure dominant & 20 & 43 & 36 & 71 & 48 & 46 \\
\hline Total number & 25 & 14 & 36 & 31 & 115 & 221 \\
\hline
\end{tabular}

While the previous scale dealt with the dominant influence in the subject's childhood, the next question asked of the subjects deals with their adult life:

Whom are you said to resemble most in the way you go about doing things?

Even though the differences between the diagnostic groups were not significant, the results are striking because the rheumatoid arthritis and ulcer patients tended to report more of a current resemblance to a masculine figure, primarily the father, than the others. These same two groups, it will be recalled, reported a feminine dominant influence during their childhood. This apparent inconsistency may, in fact, suggest the presence of a conflict in their sexual identification. The relevant data are presented in Table 7. In the upper half of the table, the subjects are divided into two groups: (1) those whose perceptions are congruent: current resemblance to a masculine figure which was also dominant in the subject's childhood or resemblance to a feminine figure which was also dominant; (2) those whose perceptions are incongruent: current resemblance to a masculine figure while a feminine figure was dominant or resemblance to a feminine figure while a masculine one was dominant. Clearly rheumatoid arthritis, hypertension, and ulcer patients reveal a greater number of incongruent perceptions. Since most of the cases of incongruence are, in fact, those of a feminine dominant influence with current masculine resemblance the same data are presented somewhat differently in the lower half of Table 7. Fully 58 per cent of the arthritis, hypertension, and ulcer cases show this incongruence, as compared with only 29 per cent of the surgical patients and controls. 
TABLE 7. ASSOCIATION OF CONGRUENCE OF PERCEPTIONS OF WHO WAS THE DOMINANT FIGURE AND WHOM THE SUBJECT RESEMBLES, WITH DISEASE CLASSIFICATION

$$
\text { (Percentage of cases) }
$$

\begin{tabular}{|c|c|c|c|c|c|c|c|}
\hline & $\begin{array}{l}\text { Rheumatoid } \\
\text { arthritis }\end{array}$ & $\begin{array}{l}\text { Hyper- } \\
\text { tension }\end{array}$ & Ulcer & $\begin{array}{l}\text { Surgical } \\
\text { patients }\end{array}$ & Controls & Total & $\begin{array}{l}\text { Statistical } \\
\text { analysis }\end{array}$ \\
\hline $\begin{array}{l}\text { Congruent percep- } \\
\text { tion (e.g., resemble } \\
\text { a feminine figure } \\
\text { who was also domi- } \\
\text { nant) }\end{array}$ & 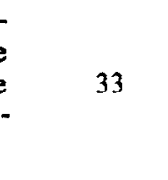 & 31 & 30 & 67 & 57 & 50 & \multirow{3}{*}{$\begin{array}{c}x^{2}=14.6 \\
4 \text { d.f. } \\
P<0.01\end{array}$} \\
\hline $\begin{array}{l}\text { Incongruent per- } \\
\text { ception (e.g., re- } \\
\text { semble a masculine } \\
\text { figure though a } \\
\text { feminine one was } \\
\text { dominant) }\end{array}$ & 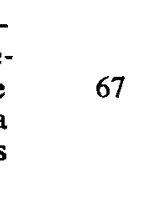 & 69 & 70 & 33 & 43 & 50 & \\
\hline Total number & 21 & 13 & 33 & 27 & 114 & 208 & \\
\hline $\begin{array}{l}\text { Resemble a mas- } \\
\text { culine figure } \\
\text { though a feminine } \\
\text { one was dominant }\end{array}$ & t & 46 & 58 & 15 & 32 & 38 & \multirow{3}{*}{$\begin{array}{c}\chi^{2}=20.6 \\
4 \text { d.f. } \\
P<0.001\end{array}$} \\
\hline All remaining Ss & 33 & 54 & 42 & 85 & 68 & 62 & \\
\hline Total number & 21 & 13 & 33 & 27 & 114 & 208 & \\
\hline
\end{tabular}

Next we shall examine two scales which are intended to measure the subject's happiness as a child and as an adult. 'The following six items refer to the subject's early life :

1. How would you rate the relationship between your parents, (very close, to very distant)?

$2 \& 3$. Please rate the feeling between you and your next older (younger) sibling, (very close, to very distant).

$4 \& 5$. Excluding illness and injury, would you say that for the respective periods life was more pleasure than pain or more pain than pleasure, (as a child, in your teens).

6. How would you rate your childhood (very happy, to very unhappy)?

The next five items form the second scale dealing with the subject's present satisfaction with life:

1. Excluding illness and injury, would you say that for the respective periods life was more pleasure than pain or more pain than pleasure: as an adult.

2. How much do you enjoy your work?

3. Do you have someone you love and if yes, how much?

4. Are you happy or unhappy in your love?

5. Please rate yourself in terms of how much fun you get out of life.

These two short scales have estimated odd-even, split-half reliabilities of 0.69 and 0.76 , respectively. They correlate only 0.28 , which suggests that they are not measuring the same underlying dimension. Tables 8 and 9 present the association of these scales with the disease classification. The ulcer patients clearly see their childhood and 
Table 8. Association of ReCalled childhoOd hapPiness With disease classification (Percentage of cases)

\begin{tabular}{lcccccc}
\hline & $\begin{array}{c}\text { Rheumatoid } \\
\text { arthritis }\end{array}$ & $\begin{array}{c}\text { Hyper- } \\
\text { tension }\end{array}$ & Ulcer & $\begin{array}{c}\text { Surgical } \\
\text { patients }\end{array}$ & Controls & Total \\
\hline Unhappy childhood & 62 & 60 & 28 & 74 & 46 & 52 \\
Happy childhood & 38 & 40 & 72 & 26 & 54 & 48 \\
\hline Total number & 13 & 10 & 18 & 31 & 83 & 155 \\
\hline & $\chi^{2}=12.4$ & d.f. $=4$ & & $P<0.025$ & &
\end{tabular}

Table 9. Association of evaluation of present happiness with disease classification (Percentage of cases)

\begin{tabular}{lcccccc}
\hline & $\begin{array}{c}\text { Rheumatoid } \\
\text { arthritis }\end{array}$ & $\begin{array}{c}\text { Hyper- } \\
\text { tension }\end{array}$ & Ulcer & $\begin{array}{c}\text { Surgical } \\
\text { patients }\end{array}$ & Controls & Total \\
\hline $\begin{array}{l}\text { Unhappy adult life } \\
\text { Happy adult life }\end{array}$ & 54 & 90 & 33 & 61 & 35 & 45 \\
& 46 & 10 & 67 & 39 & 65 & 55 \\
\hline Total number & 13 & 10 & 18 & 31 & 83 & 155 \\
\hline & $\chi^{2}=16.3$ & d.f. $=4$ & & $P<0.005$ & &
\end{tabular}

present adult life as more happy than the other three groups of patients. On the other hand, the surgical cases, and the hypertensives appear notably unhappy.

The reader will recall that on one question .... "Excluding illness and injury, would you say that for the respective periods life was more pleasure than pain or more pain than pleasure?" ... . we have the subjects' retrospective self-reports for three different periods: as a child, in the teens, and as an adult. This enables us to look at variations in scores within each subject, that is, we can use the subject's own time perspective and see how his evaluation of his adult life compares with his evaluation of his childhood and his teens. The relevant data are presented in Fig. 1. The raw data have been converted into standard scores (raw score minus the mean, divided by the standard deviation) and the zero point has been set at the mean value for all subjects and all three periods. Since we are interested in differences in patterns across diagnostic groups, the appropriate way to evaluate the results would be to treat the problem as a two-way analysis of variance with repeated measurements, and to look for a significant interaction effect. However, this is not feasible because of the unequal numbers in the different groups. Consequently, separate one-way analyses of variance were run on three sets of difference scores: (a) childhood $v s$. teens (not significant); (b) childhood vs. adulthood $(F=2.54 ;$ d.f. $=4: 146 ; \quad P<0.05)$; and (c) teens vs. adulthood $(F-2.98$; d.f. $-4: 146 ; P<0.025$. Inspection of Fig. 1 shows that while all subjects tend to perceive their teens less pleasant than their childhood, basically only the controls perceive their adulthood as more pleasant than either their childhood or their teens. In other words, while the patient groups tend to see their lives as progressively less pleasant, the controls tend to see a considerable improvement from the time they were in their teens. 


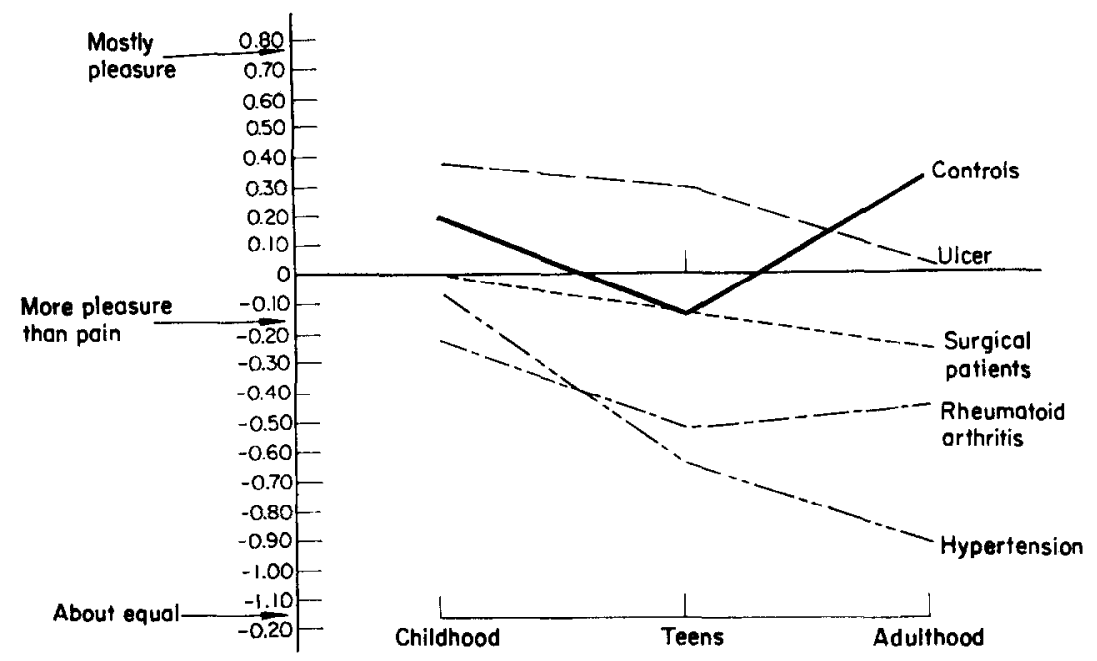

FIG. 1. Retrospective evaluation of life at three different periods by subjects in different disease categories.

It will be remembered that when we looked at the association between desire for change and self-evaluation, we found a negative correlation among the controls, but a positive one among the patients. A similar situation is found to exist when we look at the association between desire for change and evaluation of present happiness: among 83 control subjects, those who feel unhappy express a higher desire for change $(r=$ $-0.32, P<0.005$ ), whereas among the 41 patients with arthritis, hypertension, or ulcer, the association is reversed $(r=0.29, P<0.05)$. The difference between the two correlations is highly significant $(P<0.001)$. Among the 31 surgical patients, the correlation is -0.15 , which is not significantly different from the controls but is from the other patients $(P<0.05)$. It might also be noted that while the two scales, evaluation of self and of present happiness, relate similarly to desire for change, they do not correlate very highly with each other $(r=0 \cdot 25)$.

Next we shall look at the number of life crises the subjects report as having experienced in their past. They were asked to check any of the following: severe accident, severe sickness, nervous breakdown, unemployment, loss of position, loss of property, loss of a loved one, unhappy military service, and fearful combat experience. Table 10 gives the mean number of crises for each of the diagnostic groups. Since about the same proportion of patients and controls (13 per cent and 10 per cent, respectively) report severe sickness as one of their most stressful life crises, it is doubtful that the differences seen in Table 10 are simply due to more frequent reported illnesses among the patients.

We shall now turn to a part of the questionnaire where the subject was asked to answer five questions in three different ways: for himself, for his brother and/or for his brother-in-law, when either or both were also in the study sample. For example, the patients were asked on the first question, to rate themselves and their brothers in terms of how much fun each gets out of life. Then the brother was asked to rate the 
TABLE 10. RELATIONSHIP OF THE NUMBER OF LIFE CRISES EXPERIENCED TO DISEASE CLASSIFICATION

\begin{tabular}{|c|c|c|}
\hline Disease classification & $\begin{array}{l}\text { Mean number of life } \\
\text { crises experienced }\end{array}$ & No. of cases \\
\hline Rheumatoid arthritis & 1.64 & 25 \\
\hline Hypertension & 2.85 & 13 \\
\hline Ulcer & 1.83 & 35 \\
\hline Surgical patients & 2.29 & 34 \\
\hline Controls & 1.65 & 117 \\
\hline
\end{tabular}

patient and himself on the same dimension. The other four questions were as follows:

1. How easily your feelings get hurt.

2. How easily you get embarrassed.

3. Calmness in an emergency, and

4. How freely you express your emotions.

Out of these four bits of information, a discrepancy score was constructed as follows: $|(\mathrm{PP}-\mathrm{PB})-(\mathrm{BP}-\mathrm{BB})|$ where $\mathrm{PP}$ stands for patient's report on self, $\mathrm{PB}$ stands for the patient's report on his brother, etc. The score reflects the absolute value of the difference between the statement of the patient and the statement of the brother with regard to their relative positions on a 5-point scale. Such a score is derived from independent assessments of two individuals, is self-anchoring, and is realtively uninfluenced by differences in scaling between the two observers. A high score indicates a large discrepancy or disagreement about relative self-other perceptions, i.e., disagreement about which one of the two individuals reveals more of the trait in question. For example, if the patient says "my feelings are very easily hurt but my brother's are not" and the brother says that the patient's feelings are not easily hurt but that his own are. we are dealing with a large discrepancy. The results are presented in Table 11.

TABle 11. RELATIONSHIP OF tHE DisCREPANCY IN RELATIVE PERCEPTIONS OF PATIENTS AND tHEIR BROTHERS TO DISEASE CLASSIFICATION

\begin{tabular}{|c|c|c|c|c|c|c|}
\hline \multirow[b]{2}{*}{$\begin{array}{l}\text { Patient-brother } \\
\text { perceptions on }\end{array}$} & & \multicolumn{4}{|c|}{ Mean discrepancy scores } & \multirow{2}{*}{$\begin{array}{l}\text { Analysis of } \\
\text { variance }\end{array}$} \\
\hline & & $\begin{array}{l}\text { Rheumatoid } \\
\text { arthritis }\end{array}$ & $\begin{array}{l}\text { Hyper- } \\
\text { tension }\end{array}$ & Ulcer & $\begin{array}{l}\text { Surgical } \\
\text { patients }\end{array}$ & \\
\hline $\begin{array}{l}\text { How easily are your } \\
\text { feelings hurt }\end{array}$ & $\begin{array}{l}\text { No. } \\
\text { Mean } \\
\text { score }\end{array}$ & $\begin{array}{l}13 \\
2.69\end{array}$ & $\begin{array}{l}8 \\
1.06\end{array}$ & $\begin{array}{l}21 \\
1.60\end{array}$ & $\begin{array}{l}21 \\
0.81\end{array}$ & $\begin{aligned} F & =6.46 \\
\text { d.f. } & =3: 59 \\
P & <0.001\end{aligned}$ \\
\hline $\begin{array}{l}\text { How easily you get } \\
\text { embarrassed }\end{array}$ & $\begin{array}{l}\text { No. } \\
\text { Mean } \\
\text { score }\end{array}$ & $\begin{array}{l}13 \\
1.85\end{array}$ & $\begin{array}{l}6 \\
1.17\end{array}$ & $\begin{array}{l}19 \\
1.84\end{array}$ & $\begin{array}{l}16 \\
1.37\end{array}$ & n.s. \\
\hline $\begin{array}{c}\text { Calmness in emer- } \\
\text { gency }\end{array}$ & $\begin{array}{l}\text { No. } \\
\text { Mean } \\
\text { score }\end{array}$ & $\begin{array}{l}11 \\
1.55\end{array}$ & $\begin{array}{l}6 \\
0.50\end{array}$ & $\begin{array}{l}20 \\
1.20\end{array}$ & $\begin{array}{l}17 \\
1.06\end{array}$ & n.s. \\
\hline Freely express emotion & $\begin{array}{l}\text { No. } \\
\text { Mean } \\
\text { score }\end{array}$ & $\begin{array}{l}16 \\
1.63\end{array}$ & 1.80 & $\begin{array}{l}22 \\
1.23\end{array}$ & $\begin{array}{l}23 \\
1.43\end{array}$ & n.s. \\
\hline Fun in life & $\begin{array}{l}\text { No. } \\
\text { Mean } \\
\text { score }\end{array}$ & $\begin{array}{l}9 \\
0.78\end{array}$ & $\begin{array}{l}5 \\
0.40\end{array}$ & $\begin{array}{l}12 \\
1.67\end{array}$ & $\begin{array}{l}20 \\
2.10\end{array}$ & $\begin{aligned} F & =3.13 \\
\text { d.f. } & =3: 42 \\
P & <0.05\end{aligned}$ \\
\hline
\end{tabular}


The striking findings from this table are located in the four corners. If one is permitted to interpret these discrepancy scores as indications of adequacy of communication with respect to the five areas under consideration, then it would appear that with respect to 'hurt feelings' the surgical patients communicate better than the arthritics and with respect to 'fun out of life' the reverse is true. The variations in the discrepancy scores for the three remaining scales appear to be due to chance. The highly significant findings with regard to hurt feelings suggests that the hypothesis that rheumatoids learn to hide their hurt feelings [7] and are reticent about expressing their dissatisfactions [4] may be correct.

In turning to the last part of the questionnaire, we will be looking at the subject's self-reports about their aggressive behavior, their impulsiveness, and their anger. Since our major aim here is to replicate, on a different population, the findings of a previous study [8], it is necessary, first of all, to describe that study briefly. The subjects were non-hospitalized male workers, primarily craftsmen, coming from a single industrial setting. On the basis of physical examinations and medical interviews, as well as company medical and personnel records, the workers were classified into the following diagnostic groups: rheumatoid arthritis, hypertension, ulcer (duodenal), and frequent illness behavior. The subjects in the last group showed a high frequency of illness absences and medical dispensary visits for illness without receiving a positive diagnosis on any of the three specific diseases. From test and questionnaire data, three scales were constructed: (1) Scale A, overt aggressiveness; (2) Scale B, impulsiveness; and (3) Scale C, anger-irritation. Inasmuch as similar results were obtained with the latter two scales, they were combined into a single scale (for further details, see the original publication).

In the present study, Scale A (overt aggressiveness) contains six items and is an exact duplicate from the previous study. The answers in parentheses are those which lead to a high score on the scale:

1. Sometimes I feel like swearing (True).

2. Sometimes I feel like smashing things (True).

3. I am often said to be a hothead (True).

4. At times I feel like picking a fight with someone (True).

5. I am said to have a temper now (True).

6. When you are furious, what would you do? (Swear, hit or kick something or somebody, clench fist.)

Scale B \& C, anger-impulsiveness contains eight of the eleven original items:

1. I am apt to show off if I get a chance (True).

2. I keep out of trouble at all costs (False).

3. Sometimes I pretend to know more than I really do (True).

4. I like large noisy parties (True).

5. I often act on the spur of the moment without stopping to think (True).

6. How freely do you express your emotions? (Freely, most of the time.)

7. When was the last time you were really angry? (Last week, last month.)

8. How often do you feel a little angry or annoyed? (Quite often, sometimes.)

Below we shall present the findings from the present study and compare them with those from the previous onc. In order to make the two scales fully comparable, the three items on Scale B \& C, missing in the present study, were taken out and the B \& C scores in the old study were recomputed for all subjects.

The subjects from the two studies are practically identical with respect to age, education, and occupation. However, they differ in two significant respects which limit our comparison of findings. First, the subjects in the present study are hospital- 
ized. This may imply differences in severity of disease as well as whatever other factors are associated with hospitalization. Second, the surgical patients and the frequent illness behavior individuals have little in common. Certainly, they are not suffering from the same diseases. However, they may be compared on the grounds that both groups have undertaken some health action, have entered the sick role [9], and probably have a higher propensity for adopting the sick role [10]. That is, what they have in common is 'illness behavior' [11] rather than a specific disease. In any case, in Fig. 2, which summarizes the findings, the two groups are kept separate.

TABLE 12. Relationship OF OVERT AGGRESSIVENESS TO DISEASE CLASSIFICATION (Percentage of cases)

\begin{tabular}{lcccccc}
\hline $\begin{array}{l}\text { Score on } \\
\begin{array}{c}\text { Scale A } \\
\text { (overt } \\
\text { aggressiveness) }\end{array}\end{array}$ & $\begin{array}{c}\text { Rheumatoid } \\
\text { arthritis }\end{array}$ & $\begin{array}{c}\text { Hyper- } \\
\text { tension }\end{array}$ & Ulcer & $\begin{array}{c}\text { Surgical } \\
\text { patients }\end{array}$ & Controls & Total \\
\hline Low & 54 & 90 & 56 & 30 & 45 & 48 \\
High & 46 & 10 & 44 & 70 & 55 & 52 \\
\hline Total number & 1.3 & 10 & 18 & 23 & 91 & 155 \\
\hline & $x^{2}=10.8$ & d.f. $=4$ & $P<0.05$ & &
\end{tabular}

Tables 12 and 13 give us the association of the two scales with disease classification, as seen in the present study. Tables 14 and 15 compare the results from the two studies. In the latter two tables, we are specifically interested in seeing whether or not the association between a scale and the disease classification is the same in both samples. For this purpose, the results are analyzed by a method known as partitioning of chi-square $[12,13]$. This procedure is fully analogous to a two-way analysis of variance. It can be seen that in neither case do we have a significant interaction, that is, the association between either scale and disease classification does not vary significantly in the two different studies. In addition, it may be noted that the means of the control groups from the two studies do not differ significantly from each other on either of the two scales.

TABLE 13. RELATIONSHIP OF ANGER-IMPULSIVENESS TO DISEASE CLASSIFICATION (Percentage of cases)

\begin{tabular}{lcccccc}
\hline $\begin{array}{c}\text { Score on } \\
\begin{array}{c}\text { Scale B \& C } \\
\text { (anger- } \\
\text { impulsiveness) }\end{array}\end{array}$ & $\begin{array}{c}\text { Rheumatoid } \\
\text { arthritis }\end{array}$ & $\begin{array}{c}\text { Hyper- } \\
\text { tension }\end{array}$ & Ulcer & $\begin{array}{c}\text { Surgical } \\
\text { patients }\end{array}$ & Controls & Total \\
\hline Low & 77 & 50 & 22 & 35 & 38 & 40 \\
High & 23 & 50 & 78 & 65 & 62 & 60 \\
\hline Total number & 13 & 10 & 18 & 23 & 87 & 151 \\
\cline { 2 - 7 } & & $\chi^{2}=10.6$ & & d.f. $=4$ & $P<0.05$ &
\end{tabular}

In the next step we want to look at the relationship of disease category with a joint classification on Scale A and Scale B \& C. This is because as in the previous study, the four diagnostic groups are not fully differentiated from each other unless such a 
TABLE 14. RELATIONSHIP OF OVERT AGGRESSIVENESS TO DISEASE CLASSIFICATION COMPARING THE V.A. AND INDUSTRIAL POPULATIONS

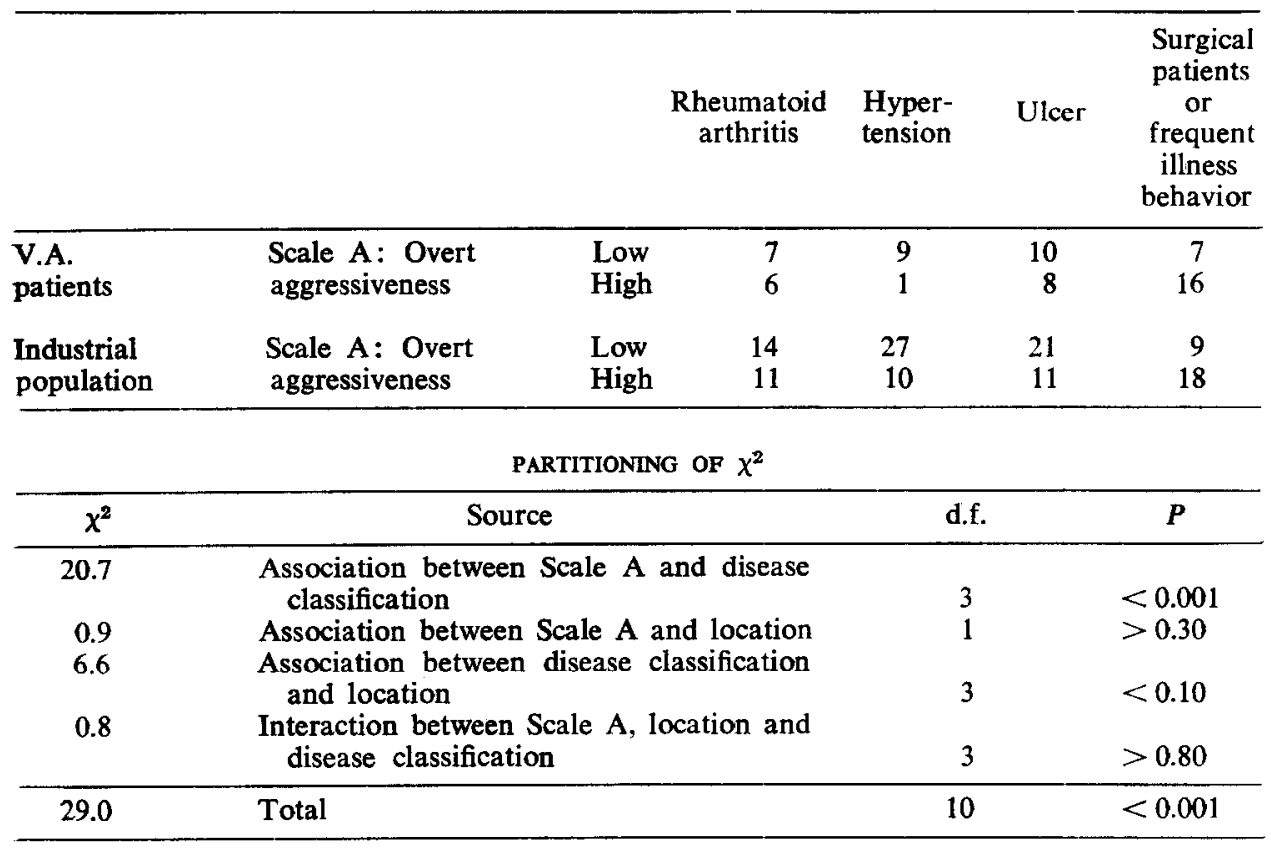

TABLE 15. RELATIONSHIP OF ANGER-IMPULSIVENESS TO DISEASE CLASSIFICATION COMPARING the V.A. AND INDUSTRIAL POPULATIONS

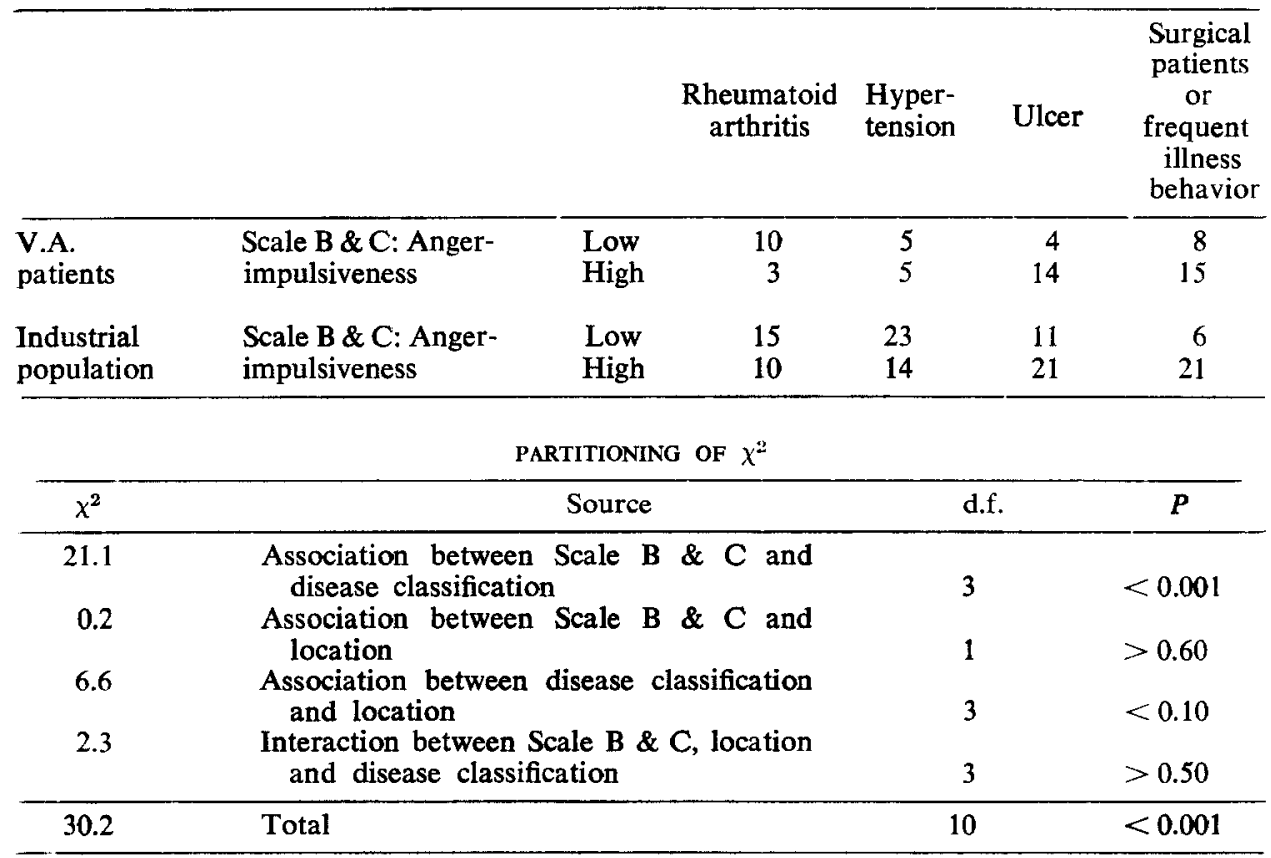


joint classification is used. The findings are given in Table 16 for the subjects in the present study and in Table 17 for the combined populations from the two studies. Such combining of populations seems justified on the grounds that Tables 14 and 15 show no significant differences due to location of study.

TABle 16. JoINT ReLATIONSHIP OF OVERT AGgRESSIVENESS AND ANGER-IMPULSIVENESS TO DISEASE CLASSIFICATION

(Hospitalized V.A. population)

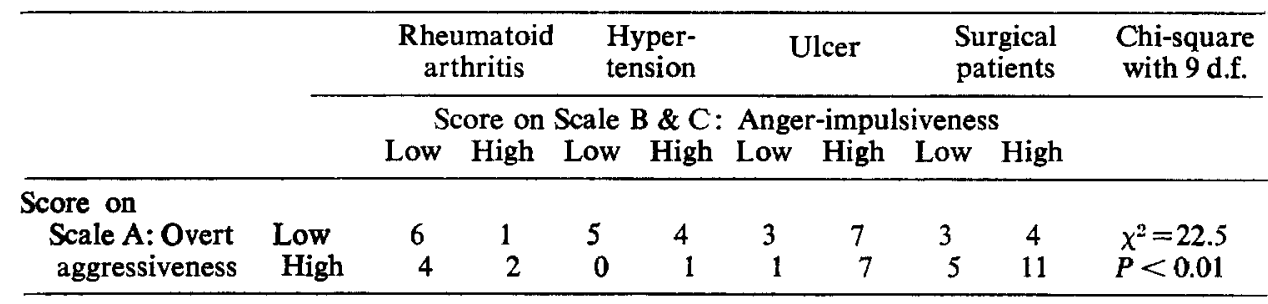

The data in Tables 16 and 17 may be analyzed by either of two comparable statistical procedures: partitioning of chi-square $[12,13]$ or the likelihood ratio test $[14,15]$. Both methods furnish a straightforward analogy to the usual analysis of variance procedures. In the present instance, the likelihood ratio test is to be preferred because some of the expected cell frequencies are too small to justify the use of the chi-square statistic. The problem in Tables 16 and 17 is treated as a three variate information transmission analysis [14] in which we are interested in the association between a joint classification, Scale A with Scales B \& C, and a third classification, disease category. The test yields a statistic, $\Lambda$, such that $-2 \log \Lambda$ is distributed as a $\chi^{2}$ with $(r s-1)$, $(t-1)$ degrees of freedom. These are the $\chi^{2}$ values given in the two tables. The important point to note is that this test disregards any association between the two scales which form the joint classification. That is, it is like a chi-square test of complete independence of three attributes in a population from which we subtract the $\chi^{2}$ attributed to the association between the two scales.

Below Table 17 we find how the control subjects distribute themselves into the four cells, formed by the joint classification on Scale A and Scales B \& C. Comparing this distribution of the control subjects with the distribution of the subjects in each disease category allows the reader to see how subjects in each disease category differ from the controls. These same data are given in Fig. 2 as a two-dimensional representation of the distances of each group from the other groups and from the controls. The intersection of the two scales, the origin or zero point, is set at the means of the scales scores of the 273 controls from both studies. The units used on the axes are in standard deviations of the respective scales. Because Scale A correlates 0.44 with Scale B \& C, the axes are drawn at an angle of $63.9^{\circ}$, instead of being orthogonal. This follows the common practice of representing the amount of correlation as the cosine of the angle. The scale positions of the subjects in the three disease categories-arthritis, hypertension, and ulcer-are given separately for the V.A. patients (connected with a double line), the industrial subjects (connected with a single line), and the combined group. The surgical patients and the frequent illness behavior subjects are kept separate. 


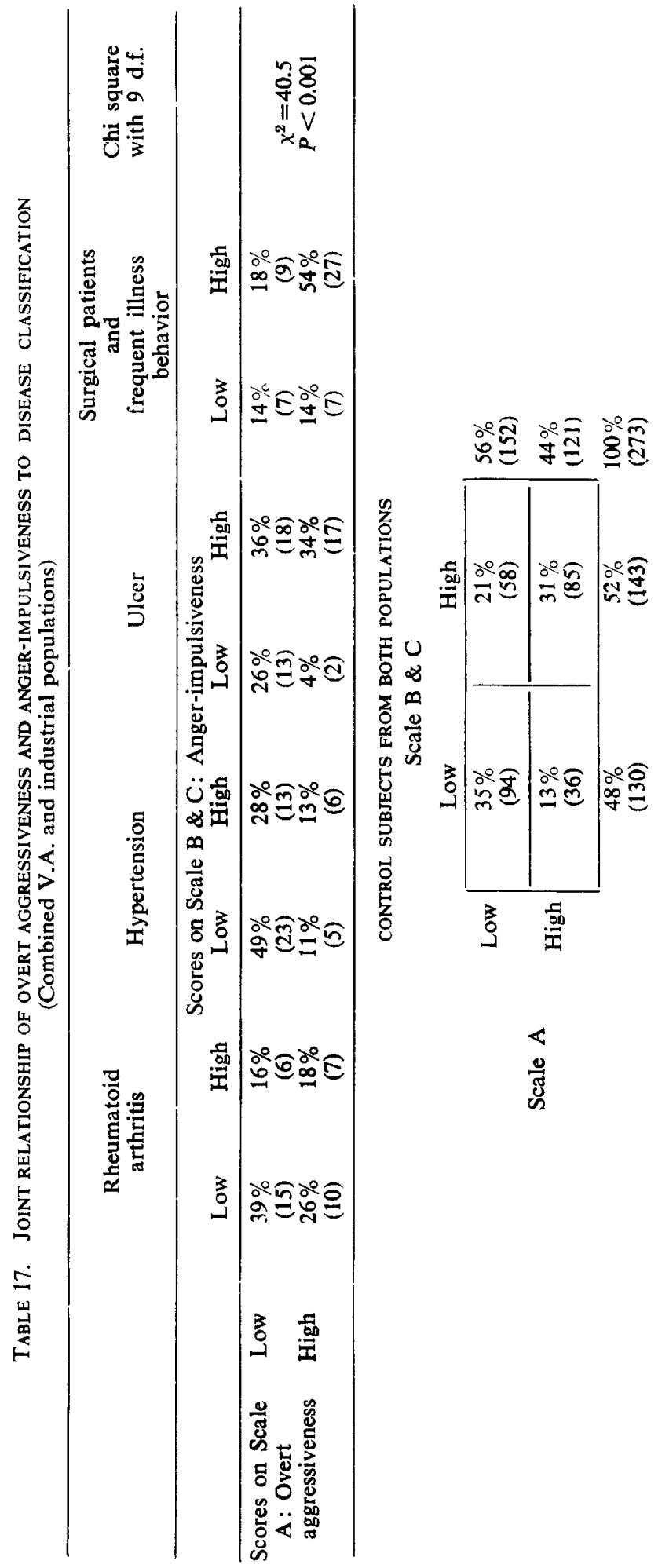




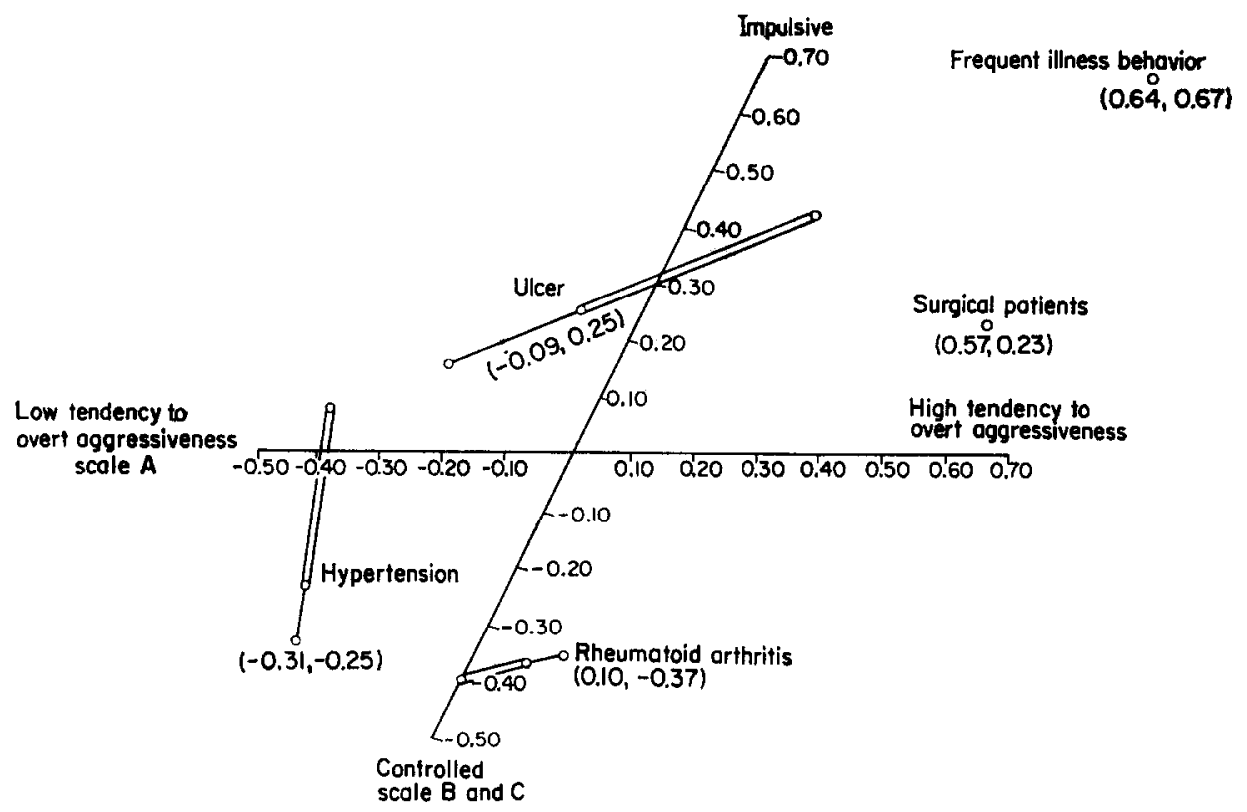

FIG. 2. The joint relationship of overt aggressiveness and anger impulsiveness to disease classification (in the combined Veterans Administration and industrial populations).

Figure 2 may be summarized with the following tentative description of five groups:

1. Rheumatoid arthritics report themselves as controlled.

2. Hypertensives report a weak tendency toward overt aggressiveness, and a variable tendency to control.

3. The ulcer cases appear to be impulsive.

4. The surgical patients and the cases of frequent illness behavior are apparently not only impulsive, but they also report strong urges to engage in over-aggressive behavior.

\section{I SCUSSI O N}

The original focus of this study was on rheumatoid arthritis and the various other groups were selected as comparison groups. This means that the interview schedule was designed to investigate hypotheses about that disease. However, when it came to the analysis of the data it became apparent that we were learning interesting things about the other patient groups even though the variables selected for study were not chosen with the central problems of hypertension, duodenal ulcer, or hospitalization for surgery in mind. It behoves us then to go back over the material just presented and review it primarily from the standpoint of the diseases.

To begin with, we should note certain variables which appear to differentiate all the hospital patients from their free living brothers and brothers-in-law. First of all, the patients appear somewhat lower on education. This may be related to the fact that we are dealing with a Veterans Administration Hospital, in which lower educational status individuals will naturally accumulate. Second, they all appear somewhat lower on self-esteem-a difference which may simply be related to the fact of hospitalization. The additional finding that the patients have a positive instead of a negative 
association between self-esteem and desire for change and between happiness and desire for change must remain, for the moment, unexplained.

In looking at the hospital patients in contrast to their brothers and brothers-in-law, we might also consider the role of object loss and depression. BECK et al. [16] suggested that loss of a parent and/or spouse may predispose to depression, while STOECKLE $e t$ al. $[17,18]$ pointed out that depression is associated with illness behavior. This leads to the hypothesis that those who have lost one or both parents before the age of 16 are more likely to be found in the hospital. In Table 18 we find modest support for this notion. It should be noted that brothers are likely to have had the same experience with parental deprivation but despite this there is a tendency for them to have had less. The only fully appropriate comparison is between the patients and their brothers-inlaw so this is the way the significance test has been done.

TABLE 18. REI.ATIONShip OF PARENTAL DEPRIVATION, DUE TO DEATH, DIVORCE OR SEPARATION OF PARENTS BEFORE AGE 16 TO THE FACT OF HOSPITALIZATION

(Percentage of cases)

\begin{tabular}{ccccc}
\hline Parental deprivation & Patients & Brothers & Brothers-in-law & Total \\
\hline Present & 28 & 20 & 11 & 22 \\
Absent & 72 & 80 & 89 & 78 \\
\hline No. of cases & 109 & 64 & 54 & 227 \\
\hline
\end{tabular}

$\chi^{2}=5.2$ for brothers-in-law $v s$, patients, with 1 d.f. $\quad P<0.025$.

The situation with regard to marital status is reviewed in Table 19. Here it is noted that the frequency of married patients is considerably less than in either of the other two groups. However, again one of the groups is biased for though a wife's brother is not necessarily married, a sister's husband is, by definition. This means that about half of the brothers-in-law had to be married in order to be selected. For this reason the comparison with brothers is emphasized. There may be several reasons for the above findings, as noted by CHEN and COBB [19] in their review of family structure in relation to health and disease. The only one relevant here, beyond the cathectic value of the marital relationship, is the obvious fact that spouses look after each other and thus keep each other out of the hospital. Further analysis of parental deprivation and marital state has shown them to be reasonably independent and additive in their effects.

TABLE 19. RELATIONSHIP OF MARTtAL STATUS TO THE FACT OF HOSPITALIZATION (Percentage of cases)

\begin{tabular}{lcccc}
\hline Marital state & Patients & Brothers & Brothers-in-law & Total \\
\hline Single & 18 & 8 & 7 & 13 \\
Married & 59 & 78 & 93 & 72 \\
Marriage terminated & 23 & 14 & 0 & 15 \\
\hline No. of cases & 109 & 64 & 54 & 227 \\
\hline$x^{2}=7.0$ for brothers $v$ s. patients, with 2 d.f. & $P<0.05$. & &
\end{tabular}


If we now direct our attention to the rheumatoid arthritics, we observe some interesting findings. The arthritics, like the other patients, are low on self-esteem, but unlike the other patients they have not striven to achieve beyond their fathers and they even now express little desire for change. They report themselves as resembling their fathers but as having been most influenced by their mothers. They appear to have poor communication with their relatives about how easily their feelings are hurt, and, they consistently are at the controlled end of the impulsiveness scale. This picture is reasonably consistent with earlier findings $[2,4,6-8,20,21]$. The striking new findings is the highly significant observation that the rheumatoids and their relatives don't report with any consistency the ease with which each other's feelings are hurt. We tend to interpret this as evidence of poor communication on this subject and suspect that the real issue is related to criticism and praise, and to the stability and vulnerability of their self-esteem. Further work is in progress to see if this matter can be clarified.

Turning now to the rather small number of hypertensives, we note that they have become increasingly unhappy since childhood to the point where they are clearly the most unhappy of all the groups. There is a suggestion that they communicate well about this unhappiness. Consistent with the unhappiness is a report of unduly frequent life crises, that confirm the report of GRAHAM et al. [22] that hypertensives see life as threatening and dangerous. On our scale of overt aggressiveness they repeatedly score low which is in line with the clinical observations and findings of several authors [23-25].

The ulcer subjects are quite willing to change, have been upwardly mobile and are consistently impulsive. This is quite the opposite of the rheumatoids. In addition they are the happiest of the patients and report happier childhood and adolescent experiences than even the non-hospitalized controls.

The surgical patients tend to report that their fathers influenced them more than their mothers; they appear high on the anger-impulsiveness scale; but the only striking thing about them is their marked tendency to overt expression of anger. This suggests the hypothesis that the overtly aggressive are more likely to get surgical therapy than those who control their aggressive impulses. Further investigation of this point is indicated.

Before concluding there are two things that deserve comment. First, this design of studying multiple patient groups simultaneously against a backdrop of non-hospitaized persons with the same age, sex, and social class distribution, the brothers and brothers-in-law, has been very profitable. We could have fallen into an awful error if we had used the surgical patients as our only control group for then we might, for example, have concluded that the hypertensives were highly controlled, when in fact they are only moderately so and the surgical patients are very aggressive in comparison to the rest of the population.

Second, though the design may be reasonably sound or even quite elegant in comparison to much of the work in the field, our measuring instruments are crude at best. We are dealing with answers to questions and indices that have largely only face validity. In one instance, Scale B \& $C$, we are even dealing with a conglomerate measure. The exciting thing is that despite the crudeness of the tools we do get striking and highly significant differences in meaningful areas. The replications between this study and certain earlier studies using different populations is especially heartening. Clearly, the next step is to sharpen the measuring instruments. 


\section{S U M M A R Y}

This study has compared male patients in a Veterans Administration Hospital with rheumatoid arthritis, hypertension, duodenal ulcer, and certain surgical conditions with their brothers and brothers-in-law. With regard to achievement, desire for change and impulsive behavior, the ulcer patients were high and the rheumatoid arthritics were low. With regard to perception of parents the rheumatoids reported themselves similar to their fathers but more influenced by their mothers while the surgical patients were more influenced by their fathers. In the area of happiness the ulcer patients appear to have led quite happylives, possibly even happier than the nonhospitalized controls while the hypertensives are most unhappy. The perception discrepancy measure suggested that the rheumatoids communicate poorly with their relatives about their hurt feelings. And finally, the measures of aggressive and impulsive behavior separated the four groups of patients from their brothers and brothersin-law and from each other in a way that is both striking and replicable.

Acknowledgements-We are indebted to Dr. W. R. MERCHANT for making possible this research on the patients of the Pittsburgh Veterans Administration Hospital; to Dr. Thomas G. BeNEDEK who supervised the selection of the cases; to Dr. JUDITH MAUSNER who assisted in the preparation of the forms, and to MARTHA WIELAND who supervised the interviewing. The data collection on this project was accomplished while the senior author was a member of the Department of Epidemiology at the University of Pittsburgh.

The work has been supported in part by each of the following grants: A-308, A-1607, MH-KG-16, 709 and AM-06928.

\section{REFERENCES}

1. Ropes, M. W., Bennett, G. A., CobB, S., JACOX, R. and Jessar, R. A.: 1958 revision of diagnostic criteria for rheumatoid arthritis, Bull. rheum. Dis. 9, 175, 1958.

2. KING, S. H. and CoBb, S.: Psychosocial factors in the epidemiology of rheumatoid arthritis, J. chron. Dis. 7, 466, 1958.

3. Wyatr, B. L.: Chronic Arthritis and Fibrositis. W. Wood, Baltimore, 1933.

4. Mueller, A. D., Lefkovits, A. M., Bryant, J. E. and Marshall, M. I. : Some psychosocial factors in patients with rheumatoid arthritis, Arthr. \& Rheum. 4, 275, 1961.

5. KasL, S. V. and French, J. R. P., Jr.: The effects of occupational status on physical and mental health, J. soc. Issues 18, 67, 1962.

6. King, S. and COBв, S.: Psychosocial studies in rheumatoid arthritis: Parental factors compared in cases and controls, Arthr. \& Rheum. 2, 322, 1959.

7. CoBB, S.: Intrafamilial transmission of rheumatoid arthritis, in Genetics and Chronic Diseases. Ed. by NeEL, J. V., ShaW, M. W. and Schul,, W. J. U.S. Government Printing Office, Washington, 1965.

8. KASL, S. V. and СовB, S.: Some psychological factors associated with illness behavior and selected illnesses, J. chron. Dis. 17, 325, 1964.

9. Parsons, T.: Definitions of health and illness in the light of American values and social structure, in Patients, Physicians, and Illness. Ed. by JACO, E. G. The Free Press, Glencoe, 1958.

10. Mechanic, D. and Volrart, E. H.: Stress, illness behavior, and the sick role, Amer. sociol. Rev. 26, 51, 1961.

11. MEchanic, D.: The concept of illness behavior, J. chron. Dis. 15, 189, 1962.

12. WINER, B. J.: Statistical Principles in Experimental Design. McGraw-Hill, New York, 1962.

13. Yule, G. U. and Kendall, M. G.: An Introduction to the Theory of Statistics. Hafner, New York, 1950.

14. MCGILL, W. J.: Multivariate information transmission, Psychometrika 19, 97, 1954.

15. MoOd, A. M.: Introduction to the Theory of Statistics. McGraw-Hill, New York, 1950.

16. BeCK, A. T., Sethi, B. B. and TUtHILL, R. W.: Childhood bereavement and adult depression, Arch. gen. Psychiat. 9, 295, 1963. 
17 Stoeckie, J. D. and Davidson, G. E. : Bodily complaints and other symptoms of depressive reaction, J. Amer. med. Ass. 180, 134, 1962.

18. Stoeckle, J. D., Zola, I. K. and Davidson, G. E.: The quantity and significance of psychological distress in medical patients: Some preliminary observations about the decision to seek medical aid, J. chron. Dis. 17, 959, 1964.

19. CHEN, E. and COBB, S.: Family structure in relation to health and disease (A review of the literature), J. chron. Dis. 12, 544, 1960.

20. KING, S. : Psychosocial factors associated with rheumatoid arthritis: An evaluation of the literature, J. chron. Dis. 2, 287, 1955.

21. Moos, R.: Personality factors associated with rheumatoid arthritis: a review, J. chron. Dis. 17, 41, 1964.

22. Graham, D. T., Lundy, R. M., Benjamin, L. S., Kabler, J. D., Lewis, W. C., Kunish, N. O. and Graham, F. K.: Specific attitudes in initial interviews with patients having different 'psychosomatic diseases', Psychosom. Med. 24, 257, 1962.

23. Shapiro, A. P.: Psychophysiologic mechanisms in hypertensive vascular disease, Ann. intern. Med. 53, 64, 1960.

24. Harburg, E., Julius, S., McGinn, N. F., McLeod, J. and Hoobler, S. W. : Personality traits and behavioral patterns associated with systolic blood pressure levels in young college males, J. chron. Dis. 17, 405, 1964.

25. Thomas, C. B.: Psychophysiologic aspects of blood pressure regulation: the clinicians view, Psychosom. Med. 26, 454, 1964. 